\title{
The Legalization through Judicial Ways of the Consumption of the Personal Drug Dose: Is It a Challenge to the Democratic System in Latin America?
}

\author{
Germán Alfonso López Daza ${ }^{1}$ \& Carlos Fernando Gómez García ${ }^{2}$ \\ ${ }^{1}$ Professor of the Law Faculty in the Surcolombiana University, Neiva, Colombia. PhD in Constitutional law \\ (Université de Paris II Panthéon-Assas - France). Director of Research group Nuevas Visiones del Derecho. \\ ${ }^{2}$ Professor of the Law Faculty, Surcolombiana University, Neiva, Colombia \\ Correspondence: Germán Alfonso López Daza, Professor of the Law Faculty in the Surcolombiana University, \\ Neiva, Colombia. PhD in Constitutional law (Université de Paris II Panthéon-Assas - France). Director of \\ Research group Nuevas Visiones del Derecho. E-mail: germanlo@usco.edu.co
}

Received: November 28, 2016

Accepted: January 2, 2017

Online Published: January 13, 2017

doi:10.20849/ajsss.v2i1.106

URL: http://dx.doi.org/10.20849/ajsss.v2i1.106

\begin{abstract}
The drug use has been treated in most of the world from a democratic aspect, having as a challenge the participation of citizens in making decisions or the contemplation of this topic by the current legislation. But Colombia has been the exception due to the permissiveness and restriction of the drug use that has been developed through the judicial channel. The Constitutional Court, on the occasion of its statements, is the one that has changed the treatment about the use and the ones who use it.
\end{abstract}

Keywords: drug use, challenge to democracy, judicial activism, constitutional court

\section{Introduction}

In most of the democracies in the world, the legislative law (Congress or Parliament) has decided about the regulation the use of psychotropic substances has. Some other countries have continued with the punitive legislations and some others have chosen the depenalization, even using a referendum as some states from the United States did.

Over the last years in Latin America, it has been implemented all kind of policies to confront the problem of using illicit drugs, having as basic pillars the depenalization or the user decriminalization and the harm reduction policy, that consists of a strategy to take the drug use as a public health issue where the dependent person is seen not as a criminalized or punished person but one that need to be assisted, instead (Latin American Commission on Drugs and Democracy, 2009).

The consumption of psychotropic substances in Latin America in the beginning had a treatment in a punitive and prohibitionist approach that has been materialized through the different national legislations that eventually has been changing to depenalization approach of the personal dose. In any case, it has always been the Congress, as the highest people's representative, who has made the decision to confront this serious social issue.

However, the Colombian case has been very different. Colombia is the only country in the world where it has not been directly the congress that has legislated and has given a treatment to the use of psychotropic substances, but it has been the Colombian Constitutional Court (C-211 of 1994. Reporting judge: Dr. Carlos Gaviria Díaz), instead. It is therefore, the only country in Latin America where the constitutional court judge is the one that has regulated the use of these drugs and not the congress of the republic.

For the research group investigio and the group Nuevas visiones del Derecho, it is important to highlight the Colombian case in front of the rest of countries in Latin America and in this way, to give an answer to the legal problem posed which consist of knowing whether the legalization of the drug use through a judicial way is a challenge to the democratic system in Latin America.

That is the reason why it was proposed as a general objective for this research, to determine whether the judicial intervention in the use of psychotropic substances in Latin America is a challenge to the democracy or whether, instead, the constitutional organ is empowered to intervene in this debate. 
To reach this objective for the investigation, it will be identified and analyzed the normative treatment that has been given to the psychotropic substances in the main countries of Latin America. It is also important to stablish whether in the Latin American countries, the constitutional court judge has intervened in the treatment of the drug use as well as determine whether the statements from the Colombian Constitutional Court about the drug use are a challenge to the democratic system.

In pursuing this objectives, it will be developed some important aspects as the experiences other countries in the world has had in the treatment of drug use and their attempts to legalized it in a democratic way, the legalization of the drug use in Urugay and the breakage of a paradigm in the Colombian case through the legalization by a judicial way.

\section{The Drug Legalization through a Democratic Way in the World}

Even though the United Nations, UN, continues to maintain its position of criminalization of drugs as attenuating to the production, trafficking and use, however, there are countries that democratically have opted for legalizing the use or allow its sale.

Holanda, since 1976, as Belgium, Portugal, Luxembourg, Austria, Croatia, Netherlands, Spain, Denmark, Moldavia, Russian Federation, and Switzerland are some of the countries from the European Union that have legalized the sale of marijuana.

From Asia, there are details that state that it was there where the marijuana was discovered for the first time (India, Pakistan and Afghanistan). However, nowadays in some countries the possession or use of it can bring them even death penalty.

In the United States, in 15 out of 50 states it is allowed to use this drug (marijuana) to medicinal purposes, therefore, it is legal to use it. In this country, the penalties are tough around the use; however, many citizens violate the law.

In Latin America, in a great group of countries it is allowed to use certain amount of drugs. In Chile, for example, the legal use is personal, (Andrade, 2013, p. 33), however, the marketing and production is prohibited; in Peru it is permitted to use it in a personal way. One can possess max. 8 grams of marijuana and 2 grams of its derivatives and in Colombia, the minimum dose is still being legal.

\subsection{Cannabis in Some European Countries}

In Germany, using drugs is to be punished for about five years in prison or a fine. In 1994, the German Constitutional Court stated that federated states should not prosecute the possession of marijuana when it is to a personal use.

The German Narcotics Law stablish that the possession of small amounts of drugs is a crime but it will not be prosecuted when: 1) There is not damage to other people; 2) There are not minors involved; 3) It has a personal use; 4) The crime implies a "negligible amount".

In Austria, the crimes related to the cannabis can be punished up to six months in jail.

In Belgium, the personal dose of marijuana is forbidden. In this way, whether there is a public disorder after using the drug, the punishment goes from three months until a year in prison.

In Cyprus, the marijuana is a substance that can cause a sentence for a life imprisonment for using it, and a penalty up to eight years for possession. Its regulation is clearly made through a democratic way.

In Denmark, as with all the different drugs, the crimes related to the cannabis are punished with a fine or an imprisonment up to two years. This prohibition is regulated in the executive order 698/1993 section 27 (1), the Law $\mathrm{N}^{\circ} 445 / 2004$ section 3 (1); and the tax directive 35/2004.

In such a way, it would be interesting to see the Holland case, a country that was announced as the freest country around the world according to the regulation of the use of drugs.

\subsection{The Famous Opium Act}

The opium act (1976) in Holland decriminalized the use of marijuana for consider it a "soft" drug, as its effects are less harmful than the hard drugs.

Thus, the possession of more than 30 grams was punished. A lower amount was considered legal. Since then, 37 years ago, the Dutch coffee shops are a symbolic emblem of liberty in this country and of a policy that is consider as a model for the sake of legalization. The possession of marijuana is not criminalized in Holland and 
the policies allow the use in these shops as long as they fulfill the requirements as: none advertisements of hard drugs, no alterations in public order, not selling to minors and not selling big amounts.

Despite this, the coffee shops owners should buy the cannabis in a legal market. Those who provide marijuana can be investigated for the Government by carrying drugs to the coffee shops (Blickman; Jelsma, 2009)

In 1996, the Dutch government decided to harden the guidelines for this model. The selling reduced from 30 to 5 grams for each transaction. "The amounts of coffee shops suffered a serious reduction: from 1.500 in the beginning, it went to 813 in 200, until 702 in 2007". (Blickman, Jelsman, 2009).

Since 2012, the coffee shops were exclusive establishments for clients with a membership card and the amount of members could not exceed the 2.000 people. Those who belong to the club are from Holland or they live in the country. The tourists were excluded. Now, Holland is seeking for delating the paradise image it has to openly use marijuana.

Contrary to the punitive policies that the UN states about the drugs, many legislators in the Netherlands believe that the problem has not been solved and that they prefer to put an end to the punitive laws. In other European Countries, they do not allow the recreational use of drugs, what has caused contrary policies aimed at criminalization.

According to the official page of Netherlands (Alcohol and Drugs, 2013), the drugs are categorized in "soft and hard". The list number One stablishes the drugs according to terms of unacceptable risks, while the list number Two lists the substances without any risk to the consumers.

Opium Act list I lists the substances that in the judgement of the government implies unacceptable levels of risk. These are known as hard drugs and include heroin, cocaine, amphetamines, LSD and ecstasy.

List II lists the soft drugs: derivatives of cannabis (hashish and marijuana) and sedatives as Valium and Serenid. Even when they are not inoffensive substances, the associated risks, in the judgement of the government, are lower than associated with the substances in List I (www.government.nl).

\section{Brazil Experience}

The "Constitution of the Federative Republic of Brazil" 1998, stablishes that Brazil is a democratic constitutional State and federal structure. In terms of the administration of justice it is entrusted to the judiciary entities. However, the federal constitution allows the federal Senate intervenes in the judicial decisions in very special occasions.

This constitution, that was approved by plebiscite, that welcomed the willingness of the people to determine the form of government, as a result it was constituted a republic and a parliamentary system. In the same way, it was chosen a "republican presidential system along with the tripartite division of power".

One of those powers is the Federal Supreme Court (FSC) that is the highest court of judiciary in Brazil and it was assigned some power typical of any Supreme Court and any Constitutional Court. In terms of its institutional function it is stablished that is to act as a "guardian" of the Federal Court, that is to say, when there are cases that implies injuries or threats to the Magna Carta, it has to be solved properly.

The Federal Supreme Court is absolutely essential in the Brazilian system because it has to decide the actions that have to do with the constitutionality of the norms. However, it has been questioned its job because its work of ensure the impartiality inherent to the judicial organs and for treating the Supreme interests of the nation, has been considered as a court influenced politically, it is to say, that in its decisions has prevailed the political orientation of its members (Political Constitution, Federative Republic of Brazil, 1988 Art. 101-103).

Despite of that, in 2002 and 2006, there have been legislative changes in the State of Brazil in what has to do with the use of psychotropic substances and its regulation. As a result, it is achieved a depenalization of the position for personal use. The punishment of prison will not be applied, it is to say, the consequence of a repressive penalty, in such a way that they were substituted by educational measures and community services.

Even when the use of drugs stopped being a crime there have been punishments of until five years in prison for the sale of small amounts. A research conducted in 2009 about the criminal processes for the drug trafficking, in Rio de Janeiro and Brasilia, showed that the penal system is selective and that those who sell small amounts of drugs constitute the $60 \%$ of the condemned (Chiquillo et. al, 2013).

In Brazil, the first national policy about controlling the use of drugs was formulated by the government of the President Fernando Henrique Cardoso, through the creation of the National Drug Secretariat that 
was intended to develop a plan that reconciled methods of repression, plans of prevention and reduction of demand. In 2006, under the governance of president Luis Inácio Lula da Silva, the drug policy was realigned with Law $\mathrm{n}^{\circ}$. 11,343 strengthening prevention programs and guaranteeing educational measures instead of user penalties, and providing space for the cultivation of plants for confirmed personal use. (Latin American Commission on Drugs and Democracy. P. 36)

According to what it was stablished, taking into account the different ways of communication, nowadays in the city of Brasilia it is being developed a campaign promoted by civil organizations aiming to achieve a depenalization of the possession of drugs in Brazil. This campaign was supported by seven ex-ministers of justice who signed a declaration of support to that cause (The New Herald, 2013).

That document, where it is stated the proposal mentioned above and the supportive signatures, was sent to the judge Gilmar Mendes from the Federal Supreme Court, who was the rapporteur of a possession of drug case where the resolution of the process must be applied for other courts in similar cases to the possession of drugs for personal use (laprensalatina.com).

In September 2010 the legislative option in favor of the increase of repression was questioned by the Federal Supreme Court of Brazil as well as the exclusive option for imprisonment. The court established a resource for a person accused of trafficking 13.4 grams of cocaine and argued the prohibition of the substitution of imprisonment applied to a small trafficking drug dealer by measures restricting rights, referred in paragraph 4 of the article 33 of the Narcotics Law. The majority determined that that prohibition was unconstitutional and it was established that the possibility of a substitution should be studied case by case. Brazil. Overview of drug laws and legislative trends in Brazil. (F.S)

Concerning the criminalization, it is stated a illegitimacy, since this is about behaviors practiced inside of an area of "individual's right to privacy", it is to say, enjoying the right of freedom of personality, also it is pointed in the declaration of the ex-ministers that they support the cause that every citizen has the freedom to build their own point of view, as long as the space of others be respected.

Regarding the use of drugs, the 2006 Law introduced a very important change with the depenalization of the use of drugs and the rejection of punishments consisting of deprivation of liberty to the consumer; even in cases involving recidivism, according to the article 28 where there are only stated alternative measures as punishment or sanction. In spite of that, another unconformity against the actual Brazilian law lies in the establishment of the use of drugs as a crime. However, as mentioned before, in 2006 it was substituted the imprisonment by community services and penalties of fines. Nevertheless, in that law it is not established a clear distinction of a person who possesses drugs for personal use and a person who is trafficking drugs based on the amount of substances they have at the time of capture, it is to say, it is not defined the strictly who can fit in each category (Brazil, 2006).

\subsection{Legislative Trends in Brazil}

The Brazilian legislation on drugs was strongly influenced by the historical drug conventions of the United Nations. Under the conventions, Brazil committed itself to fight against the drug trafficking and decrease the use and the demand of drug with by any means even the most drastic one: the penal control. In addition to the official engagement with the international system of drug control, the close diplomatic and commercial relationships between Brazil and the US led to the adoption of a prohibitionist approach according to the North American model of war against the drugs. Brazil. Overview of drug laws and legislative trends in Brail. (F.S)

In order to combat this challenge that has been presented not only in Brazil but also in Latin America in every democratic system, in this republic it is presented a reform to the law about toxics where it is proposed three items: the first consist on posing an interaction to the crack users and the increase on the penalty of drug trafficking as well as a proposal to decriminalize the possession of drugs for a personal use. And everything that has been a point of discrepancy and that is the correct distinction between the consumer and a drug dealer.

On the other hand, what this proposal aims is to allow the doses to be defined by federal authorities and that this proposal has the support of the institutions that help those who suffer from drug abuse and that this situation that is about public health, do not have any penal consequences as the cancellation. That proposal was presented in the Chamber of Deputies by the Brazilian commission of drugs and democracy in 2012 with the supportive signatures of hundreds of people.

However, this proposal would not be complete or would not be enough if there is not a modification of the Penal Code. That is why it was handed a preliminary project to the Senate the June $27^{\text {th }}-2012$ - It is also pretended a 
decriminalization of the planting, cultivation and harvesting of plants intended to the production of drugs for personal use exclusively, the possession of drugs for personal equivalent to a dose for five days.

\section{Argentina's Case}

When the Penal Code from 1921 was sanctioned, Valeria Anselmino (2011) warns, the use of drugs was not a problem. That is why this topic was apart from the interest of the cited text. However, the interest for this worldwide topic was already seen since the International Opium Convention subscribed in The Hague (23/01/1912).

However, the legislator of Argentina only contemplates the topic of the selling of medicines in an irregular form when he included, in the article 204 in the Code of 1921 that there is a punishment of a penalty to those who "being authorized to the selling of medicinal substances, sell it in a bad quality or an amount different to the medical prescriptions or several of the declared or agreed"

According to Valeria Anselmino, this rule is then modified by law 11,309 (07.02.1924) and 11,331 (07.29.1926), but with the enactment of Law 17,567 of 1968 becomes almost the original text.

Thus Article 204a is made the prescription of traffic, use and supply of drugs. However, the rules of the twenties rise by 20,509 work of the law repealing the law 17,567 and other criminal laws. Thus, the legislation concerning drug use increases this is how in 1974 and 20,771 law that adds to Article 77 of the Penal Code the meaning of narcotics is issued (Martinez A, 2006).

By 1977 , that is three years later, the law 21,566 on events which occurred in the capital of the Republic, confers jurisdiction to national criminal justice and correctional.

Starting October 1989 came into force Law 23,737, which was amended and extended by Law 24,424 of 1995. This new law made a contribution, incorporated in Article 49, not only in relation to drugs but related to the general scope of criminal law and was the figure of "repentant" (Schiavo, 2007, p. 23).

The Law 23,737 is also modified by law 26,052 (passed by Congress of the Nation on July 27, 2005). The first of these changes is related to the "own traffic" of drugs as well, a paragraph is added to Article 5 (Law 23.737) that seeks that who furnishes another person the substance for personal use, will have a penalty of six months to three years, as required by article 1 of Law 26,052 .

Another modification, which is considered of great importance is the one that has to do with the replacement of Article 34 of the Act giving jurisdiction to the ordinary courts.

\subsection{The Judgment Arriola}

The Law 23,737 is typified everything about drugs except consumption, that is production, trade, storage, transportation and advocacy of drugs is a crime in the light of this law.

The famous Judgment 'Arriola' has its history in a raid on a house occurred on January 16, 2006. The inhabitants of the residence were arrested and sentenced, while some young people, who went near to the house with up to three marijuana cigarettes, received educational measures.

A final disposal 'Arriola' established that consumption without trading it with third parties was protected by Article 19 of the Constitution. One of the judges of the Supreme Court, Eugenio Zaffaroni, said it was counterproductive foist responsibilities to the consumer as this not testify against supplying him, "if every consumer had a marijuana plant on the balcony then there would be traffic" (Bourdin, 2009, p. 13).

The President of the Supreme Court, Ricardo Lorenzetti said that "it is not only the respect of the actions taken in private, but the recognition of an area in which every adult individual is sovereign to make free decisions about lifestyle they want ". The judgment Arriola considered that only the person with the drugs would be evaluated to be taken when being captured. The amount was the subject of another analysis.

The precedent of 'Judgment Arriola' of the Supreme Court of Argentina challenged the democratic system in this country to request the legislature to modify the current law (23.737) and at the same time it adopted the jurisprudence of this court. This situation showed the obvious tension between the two branches of government.

Despite this situation, in August 2009, the Supreme Court of Argentina ruled in the historic "Arriola ruling" unconstitutional prosecute citizens to use drugs for personal use. Thus the judgment sought to set a precedent in the sense that adults should be free to make decisions about their lifestyle without government intervention. In the aforementioned decision, the Court urges the national legislature to amend the current law to suit settled caselaw.

The background related to drug use, go back to year 1986 to the Bazterrica sentence that decriminalized marijuana possession for personal consumption. In 1990 the judgment Montalvo again criminalized possession for 
consumption. In February 2009, Room I of the House Criminal and Federal Correctional in the ruling " Dora, Carlos and other s / dismissal " declared the unconstitutionality of Article 5 of Law 23,737. It was determined that four pots of marijuana, weighing $75 \mathrm{~g}$, were for personal consumption.

Even before judgment Arriola, most cases of holding minimum quantities of narcotics were closed before starting to be investigated (Federico, 2006, p. 180).

\section{Experience in Peru}

Regarding the outlook for the legislation in the Republic of Peru, the traditional use of the coca leaf is recognized, which is accepted as a cultural practice and has never been penalized; however in this country a licensing system controlled by the state, which is called _there, "registration", meaning that for the cultivation of the coca leaf and its respective distribution company-controlled ENACO (Empresa Nacional de Coca). However, as in most Latin American countries the use of psychoactive substances or possession of them for personal use are punishable, but its micro-market or traffic, which is a concurrent crime in this country.

With respect to legislation on illicit drug trafficking is determined as punishable behavior, as enshrined in Articles 296 to 303 of the Penal Code of 1991. This means that treatment started from this year and as time has been supplemented to rules such as the law 28002 of June 17, 2003 (www.druglawreform.info).

According to Articles 296 and following of the Penal Code, offenses against public health, constitute offenses the following conduct: 1) To promote, encourage or facilitate illegal drug use through acts of manufacturing or trafficking; 2) Possessing drugs for sale (traffic); 3) Commercialize inputs for the illicit manufacture of drugs; 4) Commercialize or cultivate poppy or marijuana or force planting or processing; 5) Compelling or inducing others to use illegal drugs.

Concerning illegal marketing of drugs, there are two types: traffic and micro-marketing (sales of illicit drugs in small scale up to $50 \mathrm{~g}$ of $\mathrm{PBC}, 25 \mathrm{~g}$ of cocaine, 5 grams of opium latex and 10 grams of marijuana - reason that has a lesser penalty), as prescribed by the Criminal Code of Peru, Law No. 27,146.

Thus it can be said that there is no provision to sanction or punish the consumption or possession of drugs, provided it is for personal consumption. Despite this and as we say some critics, due to poor legislative technique has been paid to give misinterpretations, meaning that the mere possession for personal consumption, constitute a criminal offense, as the guideline of the penal code establishes a limit for such possession, but does not mean that person is credited with the offense, as long as it is not intended for marketing.

\section{Chile's Case}

By 2012, in Chile, there were presented before parliament legalization initiatives by Senators Fulvio Rossi and Ricardo Lagos Weber, who proposed a bill that sought to authorize self-cultivation of marijuana, as well as to allow its personnel and therapeutic use. Thus, the bill would amend Article 50 of Law 20,000 on Illicit Drug Trafficking.

The current law in Chile is law 20,000 promulgated and published in February 2005, which replaces the 1995 Law 19,366 punishes illicit trafficking in narcotic drugs and psychotropic substances. In this way the current law in Chile, punishes those who:

"Whoever without the proper authorization possesses, transports, stores or carries along small amounts of substances or narcotic or psychotropic drugs, producing physical or psychological dependence, or raw materials that serve to get them. He shall be punished by imprisonment in its medium to maximum degrees and a fine of ten to forty monthly tributary units, unless justified that are intended for the care of a medical treatment or use or exclusive and close personal consumption over time. The same penalty shall incur the acquiring, transferring, providing or facilitating any capacity small amounts of these substances, drugs or raw materials, with the aim of to be consumed or used by another." (Ministerio del Interior Chile. 2005)

\section{Ecuador's Case}

In the case of Ecuador, the new Constitution approved by referendum in September 2008 established on drug users that "in no case shall they be criminalized nor their constitutional rights will be infringed upon" (Constitution of Ecuador, 2008, art. 364) (Note 1).

The law that regulates matters related to drug use is the law of Narcotic Drugs and Psychotropic Substances or Law 108, which is in force since 1990. Since then, the country began a political process on the reform of the law, Substances Act narcotic and Psychotropic (Act 108). A new Code of Criminal Integral, currently being negotiated in the National Assembly, proposes a comprehensive reform to the entire penal legislation and its 
implementation, including drug law and its rulings. The reform in general tends to amend the disproportionate nature of the penalties and to emphasize the effectiveness of policies less repressive. In these changes the government has to respect the principle preserved in the new Constitution of 2008 which says that the problem of drug abuse is a public health problem and, referring to users, "in no case shall they be criminalized nor violate their constitutional rights".

\section{Mexico's Case}

Mexico has been recognized Latin American and worldwide as one of the countries with the largest drug trafficking in the world. This situation has generated a frontal fight against this scourge by successive governments, which at the same time has led to a steady decline in social, economic and political aspects. The fight against drugs has generated a real war and a constant challenge, as it has been sought with constant laws and policies at least a reduction of this problem.

In April 2009, the Congress adopted the 'Narcomenudeo decree', removing any sanctions for quantities for personal use: 5 grams of cannabis, 2 grams of opium, 0.5 grams of cocaine, 50 milligrams of heroin or 40 milligrams of methamphetamine. Addicts will be subjected to mandatory treatment only after the third arrest. The decree came into force in August 2009.

The law strictly defines personal dose which could lead to prison sentences for those who are surprised with greater amounts than the allowed. In September 2010, the Supreme Court of Justice of the Nation (Supreme Court) declared valid law reform.

Former Mexican President Felipe Calderon sent draft legislation decriminalizing the possession of small amounts of drugs in order to keep his crusade against drug trafficking alive and calm the violence in the streets. Calderon's initiative proposes that users are not punished with whom up to two grams of marijuana, 50 milligrams of heroin, 500 milligrams of cocaine and 40 milligrams of methamphetamine.

The measure seeks to differentiate, legally, the consumer, the supplier and seller of drugs. "What is sought is to treat the addict as a criminal, but as a sick and give psychological or medical treatment," said Senator Alejandro Gonzalez, president of the Justice Commission of the Mexican Senate. (Latin-American Commission about drugs and democracy 2004, p. 36).

Legislation for drugs in Mexico is established in the General Health Law 1984, the Act also everything else are regulated on drugs as set out in the Federal Penal Code following the reforms of 1994. Moreover in 1996 the Federal Law against Organized crime, which exponentially increased the penalties for any crime committed in a considered criminal association created. Similarly, the August 21, 2009 came into effect a decree amending the General Health Law, the Federal Penal Code and the Federal Code of Criminal Procedure. The decree is popularly known as "Drug Trafficking Act" as its main objective is precisely to combat the drug trade mode of retail. The decree also determines maximum quantities of various narcotics or psychoactive substances permitted for personal consumption (http://www.druglawreform.info).

\section{Legalization of Consumption in Uruguay}

Regarding Uruguay, the Constitution does not enshrine an article specifically prohibiting drug use but does not say that it is permissible recreationally, but in Article 41 determines that the State will legislate on all matters relating to health and public hygiene.

Legislative power, in accordance with the powers granted by the Constitution, has in its functions to create a policy framework related to drug use, seen and listed as a public health problem. Otherwise, it states that aspect from consumption be regulated, as carrying and trafficking of psychoactive substances, which allows us to deduce that drugs are not currently banned.

Decree Law 14,294 establishes that is exempt from punishment in their possession that a reasonable amount destined exclusively for their personal consumption in accordance with the moral conviction that the judge forms in relation to this. Thus what is penalized in Uruguay is the bearing that is used to traffic and not used for own consumption.

Any kind of traffic, whether raw materials for the processing of the drug as the drug already finished, we infer that the State of Uruguay has focused its anti-drug policies in individuals who are marketing with micro traffic and also with those who they are responsible for producing or importing the drug to meet demand that produces the drug. The progress made by this country against the drug war are nothing more than a response to the challenges that the democratic system against social realities as the issue of drugs is a problem that afflicts and succumbs to many countries in Latin America and the world. 
An example of failure is Colombia who has lost the war on drugs, with their prohibitionist policies against consumption. Uruguay has not faced social problems arising from consumption and trafficking of drugs yet, but has been preparing with draft projects that seek to legalize for now marijuana consumption and give the state monopoly on the production and marketing of the same to counter act criminal gangs, although this does not guarantee that they will cease to exist, as said Julio Calzada "this does not solve the phenomenon, but partly will weaken drug trafficking and break the gondola effect, which is that when a user of cannabis will look for the substance, found other potentially hazardous substances. We want to separate markets at this stage and break the dichotomy between supply control and demand reduction, with a policy aimed to both at a time" (Salgar, D. p.18, 2012).

The current repressive policy fosters confusion between assistance and control, preventing adequate care intervention on consumers, not only for being with reduced to a minimum percentage rate - the ones that are more deteriorated - but also for not being able to fully develop improvement goals of personal, family and social conditions it can be concluded that the fomentation and promulgation by States of draft laws on preventive and care treatment that have been applied to the issue of drug use has been a response to failure as consequence of the application of repressive policies and the scientific evidence internationally realizes that the prohibitionist approaches and conceptions of "war on drugs" have proven themselves ineffective in achieving its objectives and have resulted in more harm when increasing violence and corruption.

The results of prohibitionist policies have led to the democracies in Latin America, including those democracies in repressive trends that are in decline, to start implementing social policies which are not explicitly aimed at reducing drug use in society, can contribute positively in that direction.

A more efficient education system, better designed community, better programs to empower parents in raising their children and courts to do justice in a more rapid and fairly way, can reduce risk factors, this leads to break that paradigm of the prohibition and seeing the consumer not as a criminal but as a sick person who needs help and that's what is normally associated in different countries, conceiving the consumer as a person who requires assistance and providing the services requiring necessary for improvement.

What is sought is to make visible a decrease in drug use, as explained Martin Jelsma, "exempt drug users being subjected arrested and court prosecuted for drug use and acts as the acquisition, simple possession or cultivation for personal consumption (...). It generates a discharge significantly from the pressure they are subjected agencies law enforcement and judicial and prison systems, and the barriers that prevent consumers who show problematic consumption patterns approaching treatment services and reduce the damages" (Junta Nacional de Drogas, 2011).

It has been said that the decriminalization will impact many economic, social and cultural sectors; also states that the starting time is not going to do well seen by society but in the long run will prove to result in these lines of liberal thinking and policies of prevention and care will be beneficial for a society that culturally assimilated an issue that transcends borders as is the drug.

Uruguay will be the first pioneering country in Latin America that besides not banning the use and possession for personal use will mark a guideline on drug policy with the law currently pending for the production and distribution of drugs by the State, example that can serve as a guide for other countries to rethink policies relating to drugs as it was reflected in the summit of the Americas:

The leaders of the hemisphere began a valuable discussion on the world drug problem. We agree on the need to analyze the results of the current policy in the Americas and explore new approaches to strengthen this fight and to be more effective. We have given a mandate to the OAS for this purpose (The problem of Drugs in the Americas, 2013, p.8).

Making a transition from being pragmatic states that punish such conduct, to be liberal states and progressive, appropriate to the new visions framed to the needs and realities that arise in changing societies; appropriate role to legislate for the congresses of each country and create regulations - which corresponds to the Constitution and not judicial organs as happens in the case of Colombia - because we have to strike a balance in terms of the challenge that democracies when they are tapped decisions by court order, in terms of issues that must be addressed by laws and not by jurisprudential precedents as evidenced in Colombia.

\section{Breach of a Paradigm in the Colombian Case: Legalization of Personal Dose through Judicial Route}

The treatment that has been given the use of psychoactive substances, and specifically to the criminalization or decriminalization of personal dose of the same, has had birth on one hand in the judicial route by the Constitutional Court, and through legislation by through the Congress, of which treatments are different and have not kept coherence and harmony with each other. 
A significant event in Colombia was the creation of the Constitution of 1991, with which was born the rule of law as a model of State and the Constitutional Court which "is entrusted with the safeguarding the integrity and supremacy is created the Constitution". In 1994 the highest court, the Constitutional Jurisdiction ruled on the use of personal dose, so there was a jurisprudential level the decriminalization of possession and consumption of high doses of narcotics by Judgment C-221 of 1994, of the Magistrate Carlos Gaviria's speech.

This judgment marked a milestone in the history of the treatment of personal doses of psychoactive substances, as from this ruling, the Constitutional Court has maintained a consistent line of decisions, and as well as in various pronouncements has allowed personal consumption without consequences criminal, provided it is not intended for any purpose other than personal use, namely not have as marketing or other purpose.

Colombia's Constitutional Court through Judgment C-221 of 1994 refers to the nature of the constitutional judge stating the following:

The philosophy underlying the Constitution of 91 is libertarian and democratic and not authoritarian and totalitarian much less. Therefore, if the text of a standard could detach a conclusion in line with an ideology of that nature, it would be necessary in a task of syntactic harmonization incumbent on the interpreter, extracting from it a sense that not abruptly break the system but it preserve. Because the task of the judge of constitutionality does not consist in resigning itself to that the basic rule is inconsistent patchwork fabric, together irreconcilable, but to eliminate contradictions and do it reasonably. (Constitutional court, 1994, p.1)

Thus, the Colombian Constitutional Court, in exercising its function of ensuring the supremacy of the Constitution and as an interpreter of standards issued by the Congress, has tried since 1994 to present the issue of consumption of personal dose of psychoactive substances, and thus it has maintained a trend of decriminalization of such consumption.

Historically there have been changes to regulatory and jurisprudential level in relation the use of psychoactive substances, so that it has allowed us to distinguish different historical moments in the treatment that has given the legislature and on the other hand the Constitutional Court. The first legal regulation is in the Law 30 of 1986 , which criminalizes the possession and consumption of any narcotic drug, and thus sanctioned the "dose for personal use" (Constitutional court. Sentence C-491-2012) (Note 2).

The same National Narcotics Statute in Article 51 enshrined as violation bearing, conservation for the use or consumption of cocaine, marijuana or any other drug that produces dependence, in the amount considered personal dose, and imposed penalty of arrest between 30 days and one year, depending on whether or not it was a repeat offender, and internment forced to whomsoever ruled as a drug addict. (Constitutional court. Judgment C-491-2012).

Before the 1991 Political Constitution, was fully criminalized the use of psychoactive substances, and this prohibition emanated from the legislator, however, it is important to note that since consumption is penalized, the legislative route has sought to maintain this trend, even when it has not been an effective treatment for this problem to a half, and has been on the contrary, the courts, which has treated the consumption and legalization of personal dose from the year 1994 up to the present.

The legislative treatment of personal dose consumption has been reduced. On the contrary, the Constitutional Court has been the one who has developed, treated and regulated the issue of legalization or prohibition of the use of personal dose. This allows to say that the Colombian Constitutional Court has challenged within a democratic system to the legislative body which is the Congress and who within their intrinsic powers is the body responsible for legislating on the subject, plus the history of treatment of drug consumption in Colombia by the State, clearly shows that there are contradictions between the rules issued by the Congress and the pronouncements of the Constitutional Court. It is noted that the legislative route mainly uses criminalization or penalty of psychoactive substances, while the judicial route opts for the decriminalization.

Regarding the treatment developed by the Colombian government over time, it should be highlighted that both of the governments of César Gaviria (1990-1994) and of Ernesto Samper (1994 -1998) manifestations occurred where it was said that decriminalizing personal dose was contrary to the commitment to the fight against drugs and therefore should return to punish such conduct. This situation makes clear the differences between the position of the government of that time and the ruling of the Constitutional Court in 1994, for while the Court decriminalized the personal dose, the Executive is pronounced against. 
In the government of Andrés Pastrana (1998-2002) disappeared the issue of criminalization of personal dose, but at the end of his presidential term the law 745 of 2002 was promoted, where was consecrated as the possession and consumption as a violation but the measures that were adopted were only police. (Note 3)

In the government of Alvaro Uribe (2002-2010) who had broad popular support from the presidential campaign of $2002 \mathrm{had}$ proposed the need to punish again the "personal dose". It is pertinent to mention that the discussion of the criminalization of drugs returned with great intensity for this period, and thus was reflected in seven attempts to reform the Constitution, which eventually materialized through the adoption of the reform that led the Legislative Act 02 of 2009, which amended Article 49 of the Constitution, enshrining "the size and consumption of narcotic drugs and psychotropic substances is prohibited, except medical prescription" (Colombian Political Constitution 1991, art 49). The aforementioned legislative act is based on the results of a study entitled "National Study of psychoactive substances in Colombia Household" (Ministry of Justice, 2008), made by the Government.

Legislative Act 02 of 2009 was the subject of a claim of unconstitutionality by the judgment C- 574 of 2011, but the Constitutional Court declared inhibited to issue a ruling on the merits and is justified by the lack of argument of the plaintiffs and the today the Court has not actually exercised control of constitutionality to that rule.

Comparing the current legislation with reality and after analyzing the incidents and impact it has had on society, one can deduce that it is ineffective regulation, and this is reflected in the fact that currently in Colombia anyone who consumes dose staff psychoactive substances without a prescription, is not liable to punishment, and this allows us to say that the standard has been left alone in the Constitution and does not materialize in reality, namely for any consumer is unnecessary existence a medical prescription to consume the minimum dose.

So that at the legislative level currently personal consumption of psychoactive substances is prohibited, and the exception is when the person has a prescription that tells you can consume for personal use, but on the other hand there is a last and recent pronouncement the Constitutional Court which states that the use of psychoactive substances that are within what is considered personal dose has no criminal sanction, so that there is an inconsistency between the rules issued by the legislature, namely the Congress of the Republic and pronouncements issued by courts (constitutional Court and the Supreme Court), as the constitutional court through their statements makes clear that consumption of narcotics for personal use is not penalized.

When the Constitutional Court pronounced again through Sentence C-491 of 2012, makes control of constitutionality of Article 376 of the Penal Code which criminalized trafficking, manufacture or possession of narcotics. On this occasion the Court refers to the scope of the standard containing the prohibition of Article 49 of the Constitution, stating that the violation of Penal Code does not cover the criminalization of possession and consumption of narcotic drug in low doses or staff.

According to the Constitutional Court, the prohibition of possession and consumption of narcotics under Article 49 of the Constitution does not lead to its criminalization, as it is to develop prevention campaigns against the use of drugs and therefore are measures that are aimed at patient care dependent or addicted and your family; to the Constitutional Court in the case of measures to strengthen the mandate of optimizing patient care dependent or addicted and their families, through ongoing development of prevention campaigns against drug and narcotic substances, and for recovery addicts.

The State and individuals, through the health system, governed by the principles of efficiency, universality and solidarity, must provide for the application of the measures and treatments pedagogical, prophylactic or therapeutic order for addicts and dependents carry and consume narcotic drugs and psychotropic substances, informed consent and submit to them how (Constitutional court. Decision C-491-2012).

The Constitutional Court declared the conditional constitutionality of Article 376 of the reference to "trafficking, manufacturing and possession of narcotic drug" Penal Code but under the understanding that the carrying of narcotic substance, psychotropic or synthetic drug in the amount considered dose for personal use does not constitute this crime and as a result is not penalized. It also clarifies that when the carriage is within the amount of such personal dose but different purpose for their own consumption but to marketing, traffic and free distribution, such conduct is penalized because it affects among other legal property, the one of public health (Constitutional court. Decision C-491-2012).

A current example of initiatives for paradigm change in the treatment of psychoactive substances, taking into account the trend towards decriminalization consumer inclination to care, prevention and protection of consumer health and the decriminalization of psychoactive substances, manifests itself in some form on trends in treatment 
and policy different government, as is the case of creating the Advisory Commission on Drug Policy in Colombia, recently created by the Ministry of Justice and law, by resolution 0233 April 2013.

The Commission aims to analyze the results and impact of strategies that have been implemented and propose recommendations to the government for a new policy in line with the current needs of the Colombian state.

One of the first results of the Commission was the elaboration of a first report, delivered to the Government in which it recommended to target public policy in reducing drug use towards eliminating criminal penalties for consumers and use health tools public attention to the problem, the Commission proposal is geared to the drug outside the scope of criminal law and values such as health and human rights are protected. Thus the change of a trend that criminalized the consumer from a prohibitionist approach to a tilt axis whose primary prevention and comprehensive customer care reflects this in response to social demands of the country.

Similarly, there is a proposal which falls under Article 49 of the Constitution as regards the treatment that is given to a consumer of psychoactive substances and comprehensive care that gives consumers the state, as in the case of the project presented in September 2012, consisting of the creation and implementation of health care facilities for substance dependent CAMAD, project promoted by Mayor Gustavo Petro, of the city of Bogota, capital of Colombia.

These centers will have an integrated team of health professionals: a psychiatrist, psychologist, doctor, dentist and nurses. The Mayor Gustavo Petro said that "CAMAD, should be the main instrument of peace, which will be used by the Government of Bogotá Humana, hand in hand with the inhabitants of the street to dignify these human beings, regardless of their status ", so President Juan Manuel Santos authorized the supply of licit drugs to drug addicts by the District, provided it is done under medical prescription as indicated by the Constitution (Advisory Commission on Drug Policy in Colombia, 2013).

\section{Conclusion}

The results of this research are significant because it allows determining the way in which Colombia has been given the decriminalization of the consumption of the personal dose of drug and to analyze the role of the Colombian Constitutional Court in this process.

The impact caused by the ruling of the Constitutional Court has been important because the right to personal identity had a high recognition. However, drug use began to rise, and Colombia went from being a producer to a consumer country. Research on this topic has produced remarkable results on the major public health problem of recreational drug use.

This study determined how Colombia is the only country in the world that has legalized the use of the personal dose of drugs by judicial procedure

The resulting tension between the judicial decision of the court and the work of the Congress has been difficult as this has led to conflicts between the two powers that have now been overcome.

The Congress of the Republic has given a different treatment to legalization of drugs versus the treatment given by the Constitutional Court, mainly with respect to the consumption of personal use.

It is indisputable that there inconsistency between the rules and jurisprudence, because on one hand the rules tend to prohibit and penalize personal dose and have been ineffective rules, which have not fulfilled their duties, but also the judge constitutional he has favored decriminalization; the Constitutional Court challenges the democratic system in its pronouncements and has moved away from what they have prepared the prohibitionist rules.

Colombia is the only case, unlike other countries in Latin America, where drug decriminalization has been judicially. There is criticism than a Court of 9 unelected judges; he has decided a matter that should have been discussed in the natural forum of democracy, namely the Congress of the Republic. However, given the prestige of this organ of popular representation, the ordinary citizen is well disposed towards the intervention of the Court in this discussion and in most political, legal, social and economic affairs of the country, which is a real challenge for Colombian democracy.

It is up to members of the Colombian Parliament to correct this path, which so far has not been seen, because in many cases does not fulfill its duty to legislate in the frequent regulatory gaps, as recently happened with the unions of same-sex couples. Thus, the judicial activity of both the Constitutional Court and other judges will remain a real challenge to the Colombian democratic system.

Finally, it should be noted that the Colombian case is sui generis in Latin American democracy, on the understanding that while it is true the legislature is required to regulate drug use, in our case the Court 
constitutional has been who has come to define the status of the use of the minimum dose. Thus, a challenge to democracy is presented by the Court to the legislative.

However, it notes the approach that was made the Argentinean jurisprudence in the case called Arriola, highlighting the differential treatment on convictions and penalties given to who traffics drugs and who consumes.

\section{References}

Advisory Commission on Drug Policy in Colombia. (2013) Guidelines for public policy against drug use. Retrieved from http://www.usergioarboleda.edu.co/derecho_penal/pdf/LineamientosPol $\% \mathrm{C} 3 \% 83 \% \mathrm{C} 2 \% \mathrm{ADticaC}$ Consumo_ Comisi\%C3\%83\%C2\%B3nAsesora_mayo2013_FIN\%20AL.pdf

Alcaldía Mayor de Bogotá. (2012). Los CAMAD son instrumentos de paz, Alcalde Petro. Oficina de prensa. Retrieved from http://www.bogotahumana.gov.co/index.php/noticias/comunicados-de-prensa-alcalde-mayor/2083-qlos-ca mad-son-instrumentos-de-pazq-alcalde-petro

Andrade, K. (2013). Lugares del mundo donde la droga es legal. Retrieved from www.maspormas.com.

Anselmino, V. (2011). La Ley 26.052 y la competencia en materia de estupefacientes. Trabajo final de la materia Derecho Penal Intensificado IV (Problemática de los estupefacientes).

Blickman, T., \& Jelsma, M. (2009). La reforma de las políticas de drogas: Experiencias Alternativas en Europa y Estados Unidos. Nueva Sociedad. No.222.

Bourdin, M. (2009). Tenencia de drogas: tras el fallo Arriola, Zaffaroni advierte que se debe combatir el paco. Centro de Información Judicial.

Brasil: despenalización de drogas con apoyo clave. El Nuevo Herald. Retrieved from http://vivario.org.br/wp-content/uploads/2013/04/Brasil_despenalizaci\%C3\%B3n-de-drogas-con-apoyo-cla ve-2013-04-16-ElNuevoHerald1.pdf

Chiquillo, K., Méndez, G., \& Molina, C., \& Padilla, M. (2013). Factibilidad de la despenalización del delito de posesión y tenencia de drogas como forma de disminuir la delincuencia en el salvador. Retrieved from http://ri.ues.edu.sv/3411/1/FACTIBILIDAD\%20DE\%20LA\%20DESPENALIZACI\%C3\%93N\%20DEL\% 20DELITO $\% 20 \mathrm{DE} \% 20 \mathrm{POSESI} \% \mathrm{C} 3 \%$ 93N\%20Y\%20TENENCIA\%20DE\%20DROGAS\%20COMO $\% 20 \mathrm{~F}$ ORMA\%20DE\%20DISMINUIR\%20LA\%20DELINCUENCIA\%20EN\%20EL\%20SALVADOR.pdf

Comisión Asesora para la Política de Drogas en Colombia. (2013). Lineamientos para una política pública frente al consumo de drogas. Retrieved from http://www.usergioarboleda.edu.co/derecho_penal/pdf/LineamientosPol $\% \mathrm{C} 3 \% 83 \% \mathrm{C} 2 \% \mathrm{ADticaConsumo}$ Comisi\%C3\%83\%C2\%B3nAsesora_mayo2013_FIN\%20AL.pdf

Comisión Latinoamericana sobre Drogas y Democracia. Drogas Y Democracia: Hacia Un Cambio De Paradigma. Retrieved from http://www.drogasedemocracia.org/Arquivos/livro_espanhol_04.pdf

Díez Ripollés, \& José Luis. (2005). EL CONTROL PENAL DEL ABUSO DE DROGAS: UNA VALORACIÓN POLÍTICO-CRIMINAL. Revista de Derecho (Valdivia), XVIII Julio-Sin mes, 199-212.

Drogas: no es delito la tenencia mínima». La Nación (26-08-2009). (Consulted 28/05/2013).

Federico, M. (2010). País Narco. Tráfico de droga en Argentina: del tránsito a la producción propia. Editorial Random Hause. Buenos Aires.

Government of the Netherlands (Gobierno de Países Bajos). (2013). El alcohol y las Drogas. Retrieved from http://www.government.nl/issues/alcohol-and-drugs/drugs?ns_campaign=Thema-alcohol_andl_drugs\&ro_a dgrp=Drugs\&ns_mchannel $=$ sea\&ns_source $=$ google \&ns_linkname $=\% 2 \mathrm{Bdrugs} \% 20 \% 2 \mathrm{~B} \% 20 \mathrm{holland} \& \mathrm{~ns} \_$fe $\mathrm{e}=0.00 \&$ gclid $=\overline{C L}$ TRjq 49 rgCFaXm7AodukkAWQ

Junta Nacional de Drogas. (2011). Estrategia Nacional para el Abordaje del Problema Drogas 2011- 2015. Retrieved from http://www.infodrogas.gub.uy/images/stories/pdf/jnd_estrategia.pdf

Ley de Fiscalización de Estupefacientes. (2009-02-06). Reforma de la Carta. Retrieved from http://reforma-de-la-carta.blogspot.com/2009/02/ley-de-fiscalizacion-de-estupefacientes.html

Martínez, A., \& Roberto, D. Modificaciones a la Ley de Estupefacientes (ley 26.052). Revista LexisNexis, Buenos Aires No 2/2006 (Febrero). 
Ministry of Justice. (2008) National Study of psychoactive substances in Colombia. Retrieved from http://www1.urosario.edu.co/correo/administracion/boletines/ODA/documentos/ESTUDIO_NACIONAL_S OBRE_DROGAS_COLOMBIA.pdf

Online news editor. (S.F). Ex ministros defienden la despenalización Del Porte de drogas en Brasil. Retrieved from http://laprensalatina.com/exministros-defienden-la-despenalizacion-del-porte-de-drogas-en-brasil/

Organización de los Estados Americanos. (2013). El Problema de las Drogas en las Américas .P. 93. Retrieved from http://www.oas.org/documents/spa/press/Introduccion_e_Informe_Analitico.pdf

Salgar, D. (2012). Uruguay quiere un cambio. El Espectador, 18.

Schiavo, N. (2007). La Figura del "Arrepentido" en la Ley 23.737. Trabajo presentado en el curso de "Ley de estupefacientes".

Transnational Institute. (2009). Innovaciones Legislativas en Políticas de Drogas, P.4. Retrieved from http://www.tni.org/sites/www.tni.org/files/download/innovacioneslegislativas.pdf

\section{Jurisprudence}

Colombia. Constitutional court. Judgment C-221 of 1994. Reporting Judge Carlos Gaviria Díaz.

Colombia, Constitutional Court. Sentence C-491-2012. Reporting Judge Luis Ernesto Vargas Silva.

\section{Normative}

Brazil. Constitution, Federal Republic of Brazil, 1988 Art. 101-103

Colombia, Congress of the Republic. Law 30 of 1996. In: Official Journal No. 37,335 of January 31, 1986 Bogotá.

Colombia. Congress of the republic. Law 745 of 2002. "By which typifies the consumption and possession of personal dose of drugs or substances that cause dependence, with danger as violation". In: Official Gazette No. 44872 of 19 July 2002. Bogotá

Colombia. Political Constitution (1991). Art. 241.

Ecuador. Political constitution. (2008).

Uruguay. Constitution of the Oriental Republic of Uruguay. Article 41. (1967)

Uruguay. Decree Law 14,294. (1974). Art 31

\section{Notes}

Note 1. Art. 364 "Addictions are a public health. The State shall develop coordinated programs of information, prevention and control of alcohol, snuff and narcotics and psychotropic substances; as well as providing treatment and rehabilitation to occasional, regular and problem users. In no event shall they be criminalized nor their constitutional rights will be infringed upon"

Note 2. This judgment said: "Whereby the National Narcotics Statute is adopted and containing other provisions" Art. 2. Lit. j. "The amount of drugs a person carried or kept for their own consumption. Dose for personal use is the amount of marijuana that does not exceed twenty (20) grams; the marijuana hashish which should not exceed five (5) grams; cocaine or cocaine-based substance which does not exceed one (1) gram, and methaqualone which does not exceed two (2) grams. It's not for personal use dose, the drug that the person take it, when you have intended for distribution or sale, whatever their amount. "In: Official Journal No. 37,335. of January 31, 1986 Bogotá.

Note 3. Colombia. Congress of the republic. Law 745 of 2002. "By which typifies the consumption and possession of personal dose of drugs or substances that cause dependence, with danger as violation". In: Official Journal No. 44872 of July 19, 2002. Bogotá

\section{Copyrights}

Copyright for this article is retained by the author(s), with first publication rights granted to the journal.

This is an open-access article distributed under the terms and conditions of the Creative Commons Attribution license (http://creativecommons.org/licenses/by/4.0/). 